of arms; lances or javelins with a single barb; arrows, feathered on one side.

The foot of the well boasts a more unusual subject; to the left a black rhinoceros walks slowly away; in the centre, drawn in red, a halfconventionalized man is lying beside a javelin and a throwing stick. To the right, a sand-coloured bison outlined in black gazes at him; its entrails seem to be flowing out like a horse ripped open in a bull-fight. It looks like a scene in a prehistoric drama. Near the man a bird is perched on a post.

Though there may be many surprises in store when the engravings are studied, we can state already there are many horses, oxen, bison, two lions, and what seem like straw huts such as those at Altamira.

As regards the age of the engravings and paintings at Lescaux, the following are some suggestions.

In Dordogne, there are such blocks fallen on the hearths found in the Aurignacian levels and during the Perigordian epoch, in the rock shelters of Blanchard and Labattut (Sergeac) discovered by Monsieur Louis Didon. These blocks display big bichrome figures or the last of the black line drawings. This discovery permitted me to date ss of pre-Solutrean age a few figures partially hidden under the big polychromes and black shaded paintings of Magdalenian age at Font de
Gaume (Les Eyzies), Le Portel (Ariège) and Cabrerets (Lot), all of which have fine painted panels of that age. It is the same in the Cantabrian provinces; the beautiful Magdalenian frescoes of Altamira are obliterated by red line and red wash drawings, between these two black line drawings intrude.

At Cavalanes and La Haza there are only paintings in wide smudgy red lines, but at La Pasiega such paintings obliterate fine line drawings and have black drawings superposed. The stags and oxen of this ancient series have horns in twisted perspective as at Lescaux, and we have already remarked that this curious perspective is always seen in the open air art of the east of Spain from Lerida to Almeria. The only French examples are those in the rock shelter of Labattut (Sergeac) and the two at Portel (Ariège).

The similarity of the stags and oxen at Lescaux and those in the eastern Spanish art is sometimes so great that they become identical. M. Peyrony and I agree that the whole ensemble of Lescaux represents an art earlier than either the Magdalenian or Solutrean, and except in a few instances is attributable to levels later than the typical Aurignacian. As the much regretted Joseph Dechelette called Altamira "the Sixtine Chapel of Magdalenian art", so Lescaux represents with equal splendour that of the far more ancient Perigordian.

\title{
SEARCH FOR PETROLEUM IN AUSTRALIA
}

\author{
By H. B. MilNeR
}

GIR EDMUND TEALE'S recent observations on oil occurrences in Gippsland, Eastern Victoria (a summary of which appears on p. 27 of this issue), reopen in critical circumstances two fundamental though wider questions: if there exist commercial petroleum reserves in the Commonwealth of Australia, where are they and why have they not long since been exploited? Now, if ever, is surely the time to realize such assets if they are not for ever to remain frozen.

For many years past, indeed, and since before the War of 1914-18, both casual and ordered search for oil pools in this continent have occupied the attention of pioneers, mining engineers, State, Territorial and Commonwealth Government Departments, also leading oil companies. The record is long, interesting, but in results bitterly disappointing. Even so, belief in possibilities still prevails in many quarters, fostered perhaps more by political and economic than by scientific premises. Let us first briefly review geological data.

The relationship of loci of major oilfields of the Eurasian continent to the Alpine geotectonic system is a firmly established and universally recognized fact. To take the relevant segment in terms of petroleum development, follow through Irak, Iran, North-West India, Assam, Burma, Dutch East Indies to New Guinea : these proved fields in disposition themselves trace those great Tertiary earth-movements responsible for their actual oil concentrations to-day. But equally the fundamentally resistant earth masses to the south, namely, Arabia, peninsular India and, be it noted, Australia, played a significant, if passive, part in restricting the influence of this diastrophism, being themselves practically unruffled in the process.

Thus any oil pools existing in Australia must at least lack the Alpine cachet, surely a most serious 
disadvantage in that part of the globe which even the pernicious habit of wishful thinking cannot entirely overlook. In point of fact, structures impressed on these relatively static earth-masses tend to be epeirogenic and inimical to oil accumulation, even if the requisite mother-substance of petroleum is present in otherwise suitable sediments : witness the Tertiary deposits of Gippsland, almost entirely undisturbed in the sense we understand Iranian or Indo-Burman folding. Although this is all uninspiring re-statement of fact, it is surprising how often and how persistently it has been and still is disregarded.

Frankly, we must recognize that a large part of Australian territory is geologically unfavourable to localized petroleum segregation, especially in West, South Australia and Northern Territory. A fundamental Archæan and Proterozoic complex, counterpart of peninsular India, South Africa and Madagascar, constitutes not only the foundation but also much of the surface geology of this continent. Widespread developments of Palæozoic sediments sterile of oil, masses of Mesozoic epicontinental deposits, relatively undisturbed Tertiary rocks often obscured by thick Quaternary drift, a not inconsiderable development of oil shale in certain regions and an almost total absence of surface indications of petroleum throughout the continent, are basic factors to be contended with in any assessment of oil possibilities.

Even those districts offering some degree of encouragement in the past, for example, Central and Southern Queensland, Victoria, the Victoria South Australia borderland and some tracts in Western Australia, if pertinently reviewed in proper perspective, fail, at least in my opinion, to raise much enthusiasm either now or for the future.

In Queensland, at Longreach, several boreholes put down for artesian water encountered hydrocarbon gases, small oil flows and mineral wax. Wells in the Permian at Hutton Creek and Arcadia found gas, though often supercharged with carbon dioxide. Work has recently been resumed at these places and deep tests have proved 'wet' gas. Natural gas at Roma, Southern Queensland, has been known for forty years or more, and associated light oil distillates have been refined and marketed on and off since 1927. More recent drilling at Mount Basset near Roma revealed only traces of oil and gas. So in spite of widespread exploration in this area over a protracted period of time, no main oil pool has yet been located, and subsurface conditions, so far as they are known at present, do not give grounds for hope that anything spectacular lies ahead of further developments, however extensive and far flung they may be.

Tests in New South Wales, for example, Kulnura and Mulgoa, produced negative results. Search has been carried out in the Hunter River Coal Basin, also in the extensive Mesozoic deposits of south-east Queensland and north-east New South Wales, again inconclusively. It would appear that the 'oil shales' (boghead) of the Coal Measures in this State provide a clue to prevailing hydrocarbon conditions, and petroleum, if present, is nothing more than an elusive, sporadic trickle. In the former connexion it should be mentioned that intensive development of the established oil-shale field at Glen Davis, Newnes, is, according to reports received early this year, proceeding on the basis of anticipated production of 10 million gallons of shale-oil per annum, believed capable of expansion to 30 million gallons if adequate Federal subsidy is forthcoming. If such development fulfils early hopes, then this source of fuel must necessarily be of the greatest possible importance to the Commonwealth in present circumstances, especially for the Navy and in the general scheme of national defence.

Eastern Victoria boasts the only producing oil wells in the Commonwealth, at Lakes Entrance, Gippsland district. Since discovery in 1924, an emulsified oil has been obtained from which in latter years an annual production of some 25,000 gallons (!) has been recovered. Association of oil with prolific artesian water is scarcely a healthy sign, although the Imray borehole indicated that oil and water sands were separated. The trouble with Lakes Entrance is that there is no natural pressure to cause flow of oil to the wells when the sands are penetrated; hence commercial production is impracticable either by drilling or pumping. It would appear to be equally impracticable to use the underlying water to flush out the oil. Some system of air repressuring might be tried as suggested by Sir Edmund Teale, but to do this satisfactorily means effective plugging of all producing and shut-down wells, to say nothing of a financial outlay of considerable dimensions.

Although it has been reported that some 150 million gallons of oil are available here, even if economically recovered, no petrol or fractions lighter than lubricating oil could apparently be refined from it. Is such an enterprise worth while even as a war-time measure? If there is a doubt about it now, how much more hazardous would be the project in peace-time. Sir Edmund makes out a good case for speedy consideration and action by Government and other interests concerned, but even so the chances of success are not impressive. Apart from Lakes Entrance, recent drilling activi. ties at Lake Boga, Portland, and at Nelson came to naught, while another enterprise at Dutson showed no sign of oil or gas.

In the South Australia - Victoria borderland 
country, the Tertiary deposits are alleged to contain some oil, but it is probably widely dispersed. Oil seepages reported from Glenelg River when followed up led to nothing. Prospecting carried out in this region seems to have been inspired by a widespread occurrence of bitumen along the whole southern coast of the continent, quite probably washed up by prevalent Antarctic tides.

In the Kimberley region of North-West Australia trials for oil were made at Nerrima, south-east of Broome, in 1939, but no oil or gas shows of con- sequence were encountered. Again, in his report on petroleum prospects of the Kimberley district of Western Australia and Northern Territory, made more than sixteen years ago, Dr. A. Wade wrote: ". . . the area could not have been less favourable from the point of view of prospecting for, or for the finding of, petroleum supplies. It is more suited to the prospector for gold and other minerals . . ." One cannot escape the feeling that this last remark applies to a far larger part of the continent than many people realize.

\title{
THE RUBBER RESEARCH INSTITUTE OF MALAYA
}

\author{
By Sir Geoffrey Evans, C.I.E.,

\section{Royal Botanic Gardens, Kew}

\begin{abstract}
$A$ BOUT ninety per cent of the rubber in the $A$ world is manufactured from the latex of the tropical tree Hevea Braziliensis, a native of the Amazon region of South America, but now cultivated on a plantation scale in Malaya, the Netherland Indies and Ceylon, which areas produce practically all the rubber of commerce. The story of how Sir Henry Wickham managed to secure seeds of this wild tree from Brazil in 1876, and its subsequent transfer, via Kew, to the Peredeniya Gardens in Ceylon, and thence to Malaya and the East Indies, is a fascinating one. Some of the original trees are still growing at Peredeniya. From these small beginnings, the vast plantations of the Far East have their inception. In Malaya alone the area under rubber amounted to more than three and a quarter million acres in 1937, and the exports to nearly 500,000 tons, valued at nearly 350 million Straits Settlement dollars.
\end{abstract}

The industry made enormous growth at the start ; but like so many other plantation industries, it had, at a later stage, to face obstacles in the shape of lower prices and fluctuating markets following periods of over-production. The earlier planters merely cleared the forests and planted rubber and were content to collect the produce without devoting much attention to the methods of cultivation. In this respect rubber presented no difference from many other tropical plantation crops. A period of boom prices would result in the wholesale planting of areas, irrespective of soil and climatic conditions, but subsequent slumps, combined with acute competition, brought home to those interested in the industry the vital need for research and for control in the output.
With the ramifications of the rubber restriction proceedings we are not concerned; but the progress of the research work is a subject worthy of more than passing note, in view of the thorough manner in which the need has been met.

In the years immediately succeeding the War of 1914-18, the pros and cons of the matter were thoroughly thrashed out by those vitally interested in the commodity, both in London and in Malaya, and their views crystallized into the idea that a research station was needed, which would be in a position to tackle the various problems that beset the industry. The problems were many. There was first the system of cultivation. It had been considered from the first that clean weeding was essential to the successful growth of the rubber tree; but tentative experiments made by the Agricultural Department had indicated that this system was not necessarily the best, and that it resulted in the loss of much soil through erosion. Sir Lewis Fermor, in a recent report on the mining industry of Malaya, hinted that possibly as much erosion had been caused by rubber planting as by tin mining operations, which had always hitherto been blamed. Nowadays one hastens to explain this is not the case, as cover crops are the usual practice on rubber estates and clean weeding has been abandoned, and with it much erosion has been checked.

The Rubber Research Institute of Malaya was at length organized and started work in September 1926, and, after the usual teething troubles which seem to be inevitable with institutions of this nature, it can now be considered to have fairly got into its stride. A study of the annual report for 1939 gives full indication of this, and a perusal 